\title{
Review of electrostatic hazards in hard coal mining
}

\begin{abstract}
Electrostatic hazards are considered a category of technical hazards occurring in hard coal mining. These hazards are related to the generation of excess electric charges forming as a result of most technological processes. Products manufactured from plastics that are classified as non-antistatic materials pose the greatest hazard.

The article discusses the Polish and European legal regulations concerning the requirements for materials regarding their antistatic properties. It also presents the results of studies conducted at GIG concerning the systematization of the antistatic processing of plastics. Furthermore, the article proves that the procedure of applying antistatic properties to plastics is neither easy nor homogeneous. The introduced antistatic processing systematics (i.e., the identification of various antistatic processing realization methods) is meant to make both the manufacturers and customers aware of the various (often undesired) properties of modified plastics.
\end{abstract}

Key words: static electricity, mining, explosion, plastics

\section{INTRODUCTION}

The products utilized in hard coal mining must meet the requirements concerning their antistatic, slow-burning, and non-toxic properties. This is defined by the Ordinance of the Minister of Economy [1] constituting an implementing act to Mining Law [2]. An electrostatic discharge can be a source of methane ignition. The antistatic character of these products is neither understood unambiguously nor identically realized.

Most plastics do not meet legal requirements regarding their antistatic properties. Products manufactured from plastics tend to electrify, accumulating excess electric charges; this results in electrostatic discharge hazards that may initiate an ignition in an explosive atmosphere.

Plastics classified as electric insulators [3] are becoming increasingly more common in hard coal mining compared to antistatic materials due to their lower cost of production. In order to meet the legal requirements and lower the electrification ability of plastics, they are subjected to antistatic processing; i.e., improvement of their antistatic properties. Antistatic processing is a procedure based on changing the electrostatic properties of a product in order to increase its charge dissipation (offtake) speed and decrease its electrification ability.

Most commonly, the antistatic processing of materials is performed in order to change their resistivity (which is the basic material electrostatic property evaluation parameter) as well as to change the material classification - from dissipative to conductive or from insulative to dissipative. Based on their surface and volume resistivities, materials are classified as conductive, dissipative, or insulative. The first two kinds are antistatic; i.e., they do not undergo permanent electrification and do not accumulate charges on their surfaces.

There are various antistatic-processing realization methods. Many antistatically processed materials change their electrostatic properties over time or undergo changes as a result of external factor influence. Some of them also influence their surroundings. When subjected to the various antistatic processing methods, these materials are characterized by various properties that are not always desirable from the point of view of safety or their functional characteristics. An inadequate undurable product may influence the safety of explosion hazard zones. 


\section{HAZARDS IN HARD COAL MINES}

The division presented below is the author's own division based on a literature analysis (particularly of European and Polish legislation) as well as the current standards.

Hazards related to static electricity can be discussed within the context of the following areas:

- human safety and comfort,

- electronics industry and industry manufacturing elements susceptible to ESDS-type discharges,

- industry,

- explosive atmospheres, including hard coal mining,

- operating theatres.

The first hazard area is human safety and comfort. Comfort is regulated neither by legislation nor standards - no criteria or electrostatic property-testing methods have been defined. Wearing shoes or clothing classified with insulative or dissipative materials depends only on a given person. With regard to this area, a person is often electrified; electrostatic discharges tend to occur and are consequently followed by accidents (including fatal ones). As an example, we may consider limb injuries resulting from falls occurring as a consequence of an unconditioned reflex following a discharge from the human body to a metal handrail (a person in insulative shoes became electrified while walking).

From the point of view of electrostatic protection, human work safety is regulated under European law by directive [4] concerning personal protective equipment and under Polish law by the Ordinance of the Minister of Economy [5], the Ordinance of the Minister of Infrastructure [6], the Ordinance of the Minister of Infrastructure [7], and the Ordinance of the Minister of Labor and Social Policy [8]. The aforementioned ordinances constitute implementing acts to the following laws: Labor Law [9] and Building Code [10]. The requirements defined therein concern the protection from static electricity (with a particular stress on excess electrification).

The second hazard area encompasses the protection of electronic devices and devices susceptible to electrostatic discharges (so-called ESDS objects). This is an area rich in standards (PN-EN 61340 and IEC 61340 standard series). Unfortunately, this area is not regulated by legislation; i.e., the implementation of standards is not mandatory but instead constitutes a show of good will by the manufacturer or the willingness to invest in antistatic protection. How- ever, manufacturers and clients have been increasingly demanding their suppliers to implement solutions from the PN-EN 61340 and IEC 61340 standard series because, in this way, they may guarantee the quality and durability of their products (for example, ruling out the occurrence of electrostatic discharges from an employee's clothing to an electronic system). Electronic system damage constitutes a hidden fault that surfaces only during operation and is otherwise impossible to detect during production.

A multitude of standards apply to the electronics and ESD-susceptible component industries that define the control methods, testing procedures, and preventive measures meant to guarantee the safe manipulation - most often during production - of electronic elements. Electronic components (circuit boards, microprocessors) may become damaged as a result of a $50 \mathrm{~V}$ - potential discharge. In the electronics industry, applying standards describing these testing and control methods is neither mandatory nor required by law. All the more often, the application of these standard requirements by companies dealing with electronics results from the necessity to ensure product and production quality.

The third hazard area encompasses industry - particularly those branches related to hazardous and flammable materials [11]. From the point of view of electrostatic protection, human work safety is regulated under European law by directive [12] concerning machines and under Polish law by the Ordinance of the Minister of Economy [13].

Polish legislation also includes the Ordinance of the Minister of Economy [14], the Ordinance of the Minister of Transport [15], the Ordinance of the Minister of Interior and Administration [16], and the Ordinance of the Minister of Agriculture and Food Economy [17]. These constitute the implementation of acts to the following laws: Technical Inspection [18], Labor Law [9], Building Code [10], and Fire Protection [19]. The requirements defined therein concern the protection from excess electrification in areas susceptible to risks posed by electrostatic charges.

The fourth hazard area concerns explosion hazard zones. This is the most restrictive area, and the antistatic parameters defined for it arise from European Union directives, ordinances of competent ministers, and standards that constitute the implementation of the acts. Material electrostatic property control, evaluation, and certification is necessary if the said materials are to be utilized in explosion hazard zones. 
Machinery Directive 2006/42/EC [12] requires machinery manufacturers to design and implement machines and devices to prevent and reduce the accumulation of dangerous electrostatic charges or have systems to discharge electrical loads.

The ATEX Directive 2014/34/EU [25] aims to harmonize the regulations of the European Union member states regarding electrical and non-electrical equipment and protective systems intended for use in potentially explosive atmospheres. The regulations contained in this provision relate to safety and the protection of life. The directive requires the prevention of explosions by applying appropriate measures to prevent the formation of electrostatic charges capable of causing dangerous discharges.

ATEX Directive USERS 1999/92/EC [26] aims to set minimum requirements for the safety and health protection of employees in places where an explosive atmosphere may occur as well as impose specific obligations on the employer in this area. The employer's duty is risk assessment and the undertaking of technical measures to eliminate and minimize the threat, among others. The prevention of ignition is to consider the possibility of electrostatic discharge in places where the employees or work environment can be sources or carriers of voltage.

The directive on personal protective equipment 89/686/EEC [4] aims to harmonize the requirements for personal protective equipment and conformity assessment methods in the EU member states. The directive requires that personal protective equipment intended for use in potentially explosive atmospheres cannot be a source of spark or electric arc caused by electrification. The directive specifies protection measures in potentially explosive atmospheres, as antistatic products for the entire period of their application (that is, unchanging parameters). Protective measures must be made of materials that pose no threat in terms of static electricity.

Technical report CLC/TR 50404 [22] was prepared on the basis of a mandate given by the European
Commission. The report contains a number of important practical information related to the implementation of antistatic protection measures. The report contains detailed information on the safe use of the majority of commonly used materials and products in mining and potentially explosive areas. The technical report has many connections with scientific publications as well as the results of experimental work.

The Act of Geological and Mining Law [2] indicates the proper minister for the economy as responsible for defining detailed requirements for the operation of particular types of mining plants in the field of occupational health and safety.

\section{STATIC ELECTRICITY}

In electrostatics, materials are divided based on their electrostatic properties. These divisions depend on the field of application - they vary for electronics, explosion safety, and other areas.

Using the surface resistivity criterion, materials were divided into the following categories (Fig. 1): electrostatically conductive (including screening materials), electrostatically dissipative, and insulative [20].

Electrostatic charges form during electrification. Electrification (i.e., the separation of negative electric charges from positive ones) consists of isolating charges from matter or removing them from each other [21]. Electrification occurs during actions such as friction, separation, splashing, spilling, grinding, thermal shifts, mechanical processes, phase transitions, and electric induction. All of these phenomena can be easily identified not only in everyday life but also in many technological and production processes.

During electrification ability evaluations, the triboelectric series should be analyzed; i.e., the arrangement of materials based on polarity and the electric charge magnitude generated when using contact friction methods. Some materials lose electrons more easily while others accumulate them more easily (Fig. 2).

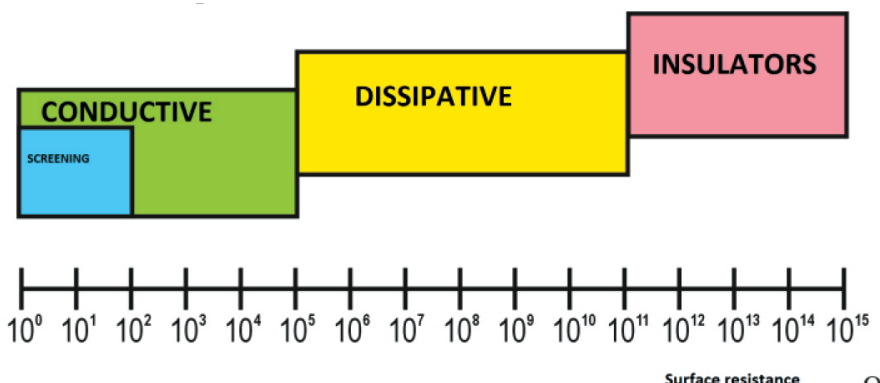

Fig. 1. Material division based on their electrostatic properties 
POSITIVE CHARGE

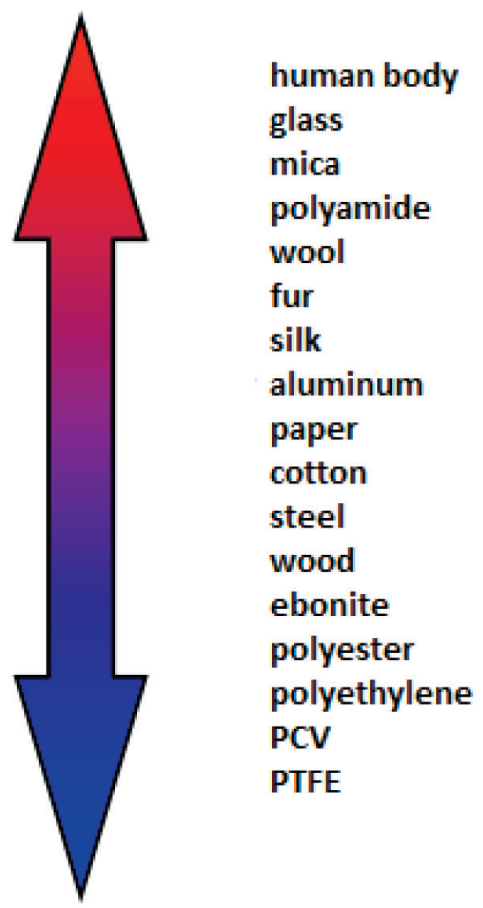

\section{NEGATIVE CHARGE}

Fig. 2. Triboelectric series

The most common electrification method is electrification through contact and friction, also called contract friction or the contact point method. An electron exchange occurs at the contact point between two bodies - a so-called double layer. Once the bodies are separated, an excess of electrons (negative charges) will occur on one of them while a shortage of electrons (positive charges) will occur on the other. The number of generated excess charges is dependent on the surface properties, material type, and environmental parameters.

According to the triboelectric series principle, materials give away or receive electrons depending on their electron affinity during separation, resulting in an electric imbalance in the materials (an excess of electrons in one and a shortage in the other). Examples may be found in lifting feet from the ground (Fig. 3) or opening a book with a foil cover.

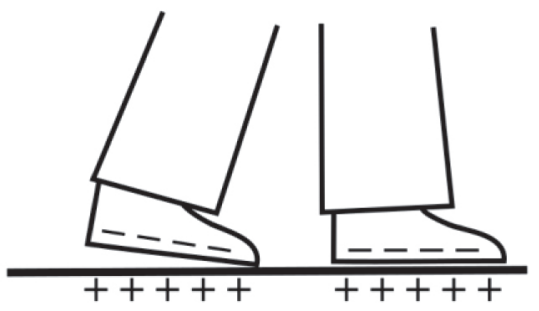

Fig. 3. Example of electrification through contactlifting feet from ground
Similar as through contact, electrification through friction is related to the triboelectric series. As a result of mechanical friction, a transfer of electric charges occurs between two bodies; this results in their electrification with an excess electric charge. When studying electric charge signs during electrification through contact friction methods, it can be concluded that, in many cases, the charge sign depends on the electrification method. No studies have been conducted concerning the influence of electrification through friction could have on electrification through contact or vice versa (including separation and striking). Electrification by breaking contact is a form of electrification through friction.

\section{ANTISTATIC PROCESSING}

Antistatic processing (i.e., applying antistatic properties to a material) is a procedure based on changing the electric properties of a product realized in order to increase the charge dissipation (offtake) speed, decrease the electrification ability, or to both increase the charge dissipation (offtake) speed and decrease the electrification ability.

Some antistatic agents (fillers) added in order to impart certain features (e.g., color) possess antistatic properties and influence the electric property changes of the modified material, but they are not treated as antistatic agents (while their use is not treated as antistatic processing).

From the point of view of electrostatic properties [22], materials are divided into screening, conductive, dissipative, and insulative properties. Surface resistivity is the criterion for this division. Due to the above, antistatic processing can be considered a procedure based on the resistivity change of a material (i.e., its change from dissipative to conductive, from insulative to dissipative, or from insulative to conductive). Antistatic processing is presented in Figure 4.

Electric capacity also has an influence on the charge dissipation speed (Relationship 1); however, antistatic processing is not identified as a change in product electric capacity, for instance, because it is hard to modify and control the electric capacity of plastics. Furthermore, there are no defined standard methods for product electric capacity measurements. Adding metal elements to a product, for example, modifies not only its electric capacity but also its resistivity. 


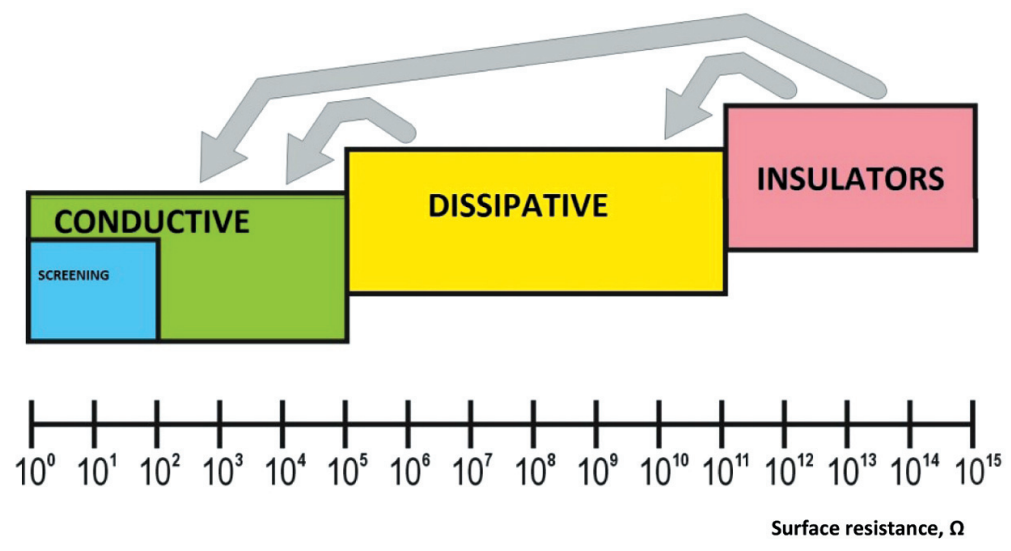

Fig. 4. Material division based on resistivity (antistatic processing)

Assuming that the antistatically processed material is grounded, then electrostatic discharges (excess electrostatic charge discharge or dissipation from the object to the earth or the grounding) can be described with the following exponential function:

$$
Q(t)=Q_{0} e^{-\frac{t}{R C}}
$$

Relationship (1) shows that product electric capacity and resistivity have a decisive influence on the dissipation speed. In the article, product electric capacity has been treated as a product feature defining its ability to accumulate charges.

Assuming that the antistatically processed material is insulated, then the total electrostatic charge generated on the material will remain on it. Whether the electrostatic charge dissipates over the entire material surface or volume or remains in its place of generation (accumulation) depends on the material's resistivity. The charge surface distribution on the insulated material has great significance because it determines the electric charge magnitude on its surface. The electric potential of the electrified object and, consequently, the electrostatic discharge energy depends on product electric capacity regard- less of the electrostatic charge magnitude accumulated on it.

\section{ANTISTATIC PROCESSING REALIZATION METHODS}

Based on the author's own studies, observations, and conclusions, antistatic processing has been divided (Fig. 5) with regard to three characteristics: the type of antistatic processing, type of preparation (utilized filler), and stage at which antistatic processing is conducted in the overall production process [23]. Using the antistatic processing division presented in Figure 5, eight methods of the antistatic processing realization methods of plastics were identified; these determine eight different types of antistatically processed materials (Fig. 6).

Each antistatically processed product may be examined according to the division pictured in Figure 5, characterizing it with regard to the type of antistatic processing, type of preparation, and stage of conduction (classifying it as one of the eight types of antistatically processed materials).

Determining eight antistatic processing realization methods of materials is significant during the evaluation of antistatic processing realization [24].

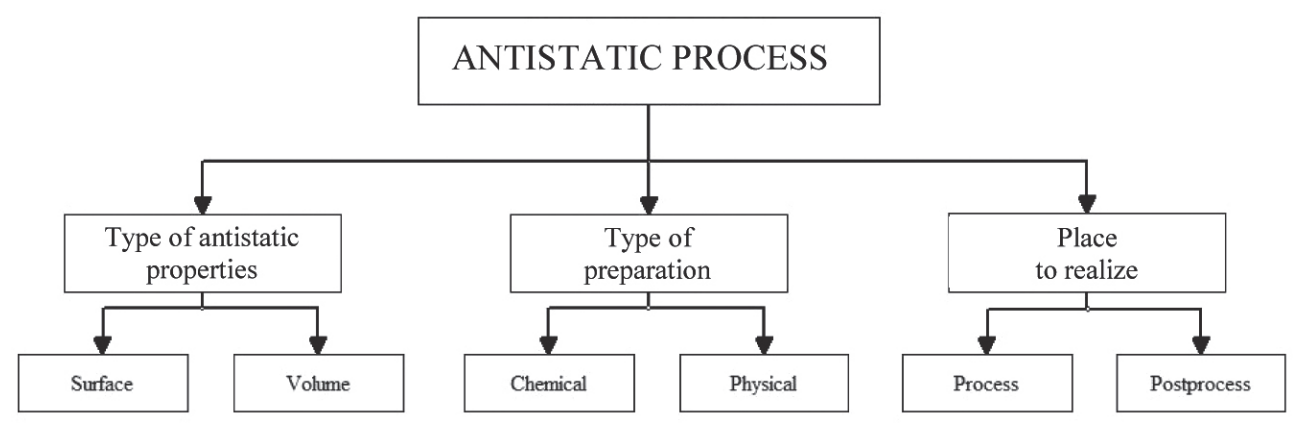

Fig. 5. Antistatic processing division 


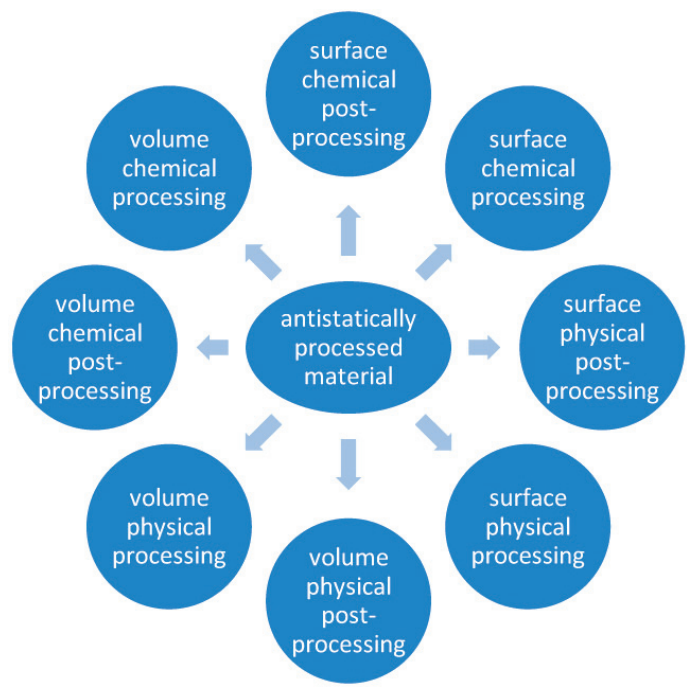

Fig. 6. Types of antistatically processed materials

\section{SUMMARY}

The article attempted to identify, characterize, and evaluate various antistatic processing realization methods of plastics commonly utilized in hard coal mining. It could seem that antistatic processing is an easy way to decrease material electrification ability. The performed identification is the author's own proposal devised on the basis of years of studies and observations as well as electric parameter correlation evaluations (interdependences and mutual relation). Based on studies and observations, different antistatic processing realization methods were identified, which are characterized by different properties directly related to explosion safety in mines. The identified antistatic processing methods were evaluated from the point of view of their safe utilization.

An appropriate material antistatic property study methodology was selected. The adopted study catalog based on the analysis of suitability for antistatic processing identification made it possible to unambiguously define the antistatic processing realization methods. Some study methods (e.g., electrification ability) were not classified as appropriate measuring methods for antistatic processing method identification. The study methods were selected in such a way so that the measurement results would provide information concerning the antistatic processing method. The proposed study method division into static and dynamic parameters made it possible to formulate conclusions concerning the interdependence of these parameters. The mutual relationships of specific electrostatic parameters (understood as the tendency of their interdependences and mutual relationships as explained in the beginning chapters of the article) describe the product according to the division adopted by the author, which includes the type of antistatic processing, type of preparation, and antistatic processing stage of conduction.

Two antistatic processing procedures were conducted for the article. A plastic material was modified during the first one - technical foil. During the second procedure, the mining foil was modified by using three different antistatic agents; additionally, each of them featured two different concentrations. The antistatic processing procedures were conducted according to the antistatic processing realization methods identified in the article.

It was also attempted to evaluate the efficiency of various antistatic processing realization methods. Efficiency should be understood as a final product evaluation and fulfilment of the planned requirements concerning the product antistatic properties. It has been proven that a part of the identified antistatic processing methods was characterized by the significant heterogeneity of the final product, the instability of its antistatic properties over time, or its influence on the environment via the exudation or flaking processes of the antistatically processed material. It was observed that the property durability of materials antistatically processed with some methods is dependent on various factors present in mines, such as the relative humidity or mine atmosphere the materials lose their antistatic properties after being flushed with water, for example.

\section{CONCLUSIONS}

The products utilized in hard coal mining must meet the requirements concerning the technical parameters defined by Polish law, ensuring their safe use. The Ordinance of the Minister of Economy, (dated June 28, 2002) concerning industrial safety, mining plant operations, and specialist fire protection in underground mining facilities [Dz.U. dated 2002, No. 139, Item 1169] constituting an implementing act to Mining Law [Dz.U. dated 2016, item 1131] permits products manufactured from plastics for use in underground mine workings if they are characterized by slow-burning, antistatic, and non-toxic properties. A literature analysis shows that a great majority of plastics do not possess antistatic properties. It can be stated that all products manufactured from plastics utilized in mining are antistatically processed because the law requires them to possess antistatic parameters. The quality of the final product utilized in a mine depends on the method and type of antistatic processing. An antistatically processed product should be 
durable over time and should not negatively influence the work comfort of miners, because the safety of the people working in explosion hazard zones in Polish underground coal mining depends on the antistatic processing realization method.

When conducting work for this article, it was observed that products utilized in underground mine workings do not meet the full safety requirements concerning the stable and safe antistatic parameters. There are products that fulfill the antistatic requirements during testing, but their properties fade after a certain amount of time. It was also observed that there are no unambiguous legal requirements concerning the electrostatic property evaluation of a product. Defining a requirement for a product to "possess antistatic qualities" is definitely too limited. They would need to be made more specific and precise. It can be concluded (for example, based on the lack of mutual electric parameter relationships of the antistatically processed products) that the current legal status qualifies products fulfilling the resistivity criterion as safe when they do not meet the charge decay time criterion or vice versa.

A dynamic increase in the contribution of plastics in the manufacturing of products utilized in industry results in the increase of the amount of plastics used in mines. The conclusions formulated in the article should be used by manufacturers of plastics utilized in Polish hard coal mining. Even through higher expenditure, the manufacturers should manufacture products that pose no risk of explosion throughout their entire period of utilization that would have stable antistatic parameters and whose antistatic processing realization methods would have no negative influence on the environment or work comfort of the underground mine personnel.

\section{References}

[1] Rozporządzenie Ministra Gospodarki z dnia 28 czerwca $2002 r$ $w$ sprawie bezpieczeństwa $i$ higieny pracy, prowadzenia ruchu oraz specjalistycznego zabezpieczenia przeciwpożarowego w podziemnych zakładach górniczych, Dz.U. z 2002 r. nr 139, poz. 1169 z późn. zm.

[2] Ustawa z dnia 9.06.2011 r. - Prawo geologiczne i górnicze, Dz.U. z 2016 r., poz. 1131, tekst jednolity.

[3] Sukiennicki A., Zagórski A.: Fizyka ciała stałego, Wydawnictwa Naukowo-Techniczne, Warszawa 1984.

[4] Dyrektywa Rady 89/686/EWG z dnia 21 grudnia 1989 r. $w$ sprawie ujednolicenia przepisów prawnych Państw Członkowskich odnoszacych się do wyposażenia ochrony osobistej.

[5] Rozporzadzenie Ministra Gospodarki z dnia 21 grudnia 2005 r. w sprawie zasadniczych wymagań dla środków ochrony indywidualnej, Dz.U. z 2005 r. nr 259, poz. 2173.

[6] Rozporzadzenie Ministra Infrastruktury $z$ dnia 12 kwietnia 2002 r. w sprawie warunków technicznych, jakim powinny odpowiadać budynki $i$ ich usytuowanie, Dz.U. z 2015 r. poz. 1422 , tekst jednolity.
[7] Rozporzadzenie Ministra Infrastruktury z dnia 6 lutego 2003 r. w sprawie bezpieczeństwa i higieny pracy podczas wykonywania robót budowlanych, Dz.U. z 2003 r. nr 47, poz. 401.

[8] Rozporządzenie Ministra Pracy i Polityki Społecznej z dnia 11 czerwca 2002 r. w sprawie ogólnych przepisów bezpieczeństwa i higieny pracy, Dz.U. z 2003 r. nr 169, poz. 1650, tekst jednolity.

[9] Ustawa z dnia 26 czerwca 1974 r. - Kodeks pracy, Dz.U. z 2014 r. poz. 1502 z późn. zm., tekst jednolity.

[10] Ustawa z dnia 7 lipca 1994 r. - Prawo budowlane, Dz.U. z 2016 r. poz. 290 z późn. zm., tekst jednolity.

[11] Walp L. E.: Antistatic Agents. Kirk-Othmer Encyclopedia of Chemical Technology 2014.

[12] Dyrektywa 2006/42/WE Parlamentu Europejskiego i Rady z dnia 17 maja 2006 r. w sprawie maszyn.

[13] Rozporzadzenie Ministra Gospodarki z dnia 21.10.2008 r. w sprawie zasadniczych wymagań dla maszyn, Dz.U. z 2008 r. nr 199, poz. 1228 z późn. zm.

[14] Rozporządzenie Ministra Gospodarki z dnia 21 listopada 2005 r. w sprawie warunków technicznych, jakim powinny odpowiadać bazy $i$ stacja paliw płynnych, rurociagi przesyłowe dalekosiężne stużace do transportu ropy naftowej i produktów naftowych $i$ ich usytuowanie, Dz.U. z 2014 r. poz. 1853, tekst jednolity.

[15] Rozporządzenie Ministra Transportu z dnia 20 listopada 2006 r. $w$ sprawie warunków technicznych dozoru technicznego, jakim powinny odpowiadać urządzenia do napetniania i opróżniania zbiorników transportowych, Dz.U. z 2015 r. poz. 34, tekst jednolity.

[16] Rozporządzenie Ministra Spraw Wewnętrznych i Administracji $z$ dnia 7 czerwca 2010 r. w sprawie ochrony przeciwpożarowej budynków, innych obiektów budowlanych i terenów, Dz.U. z 2010 r. nr 109, poz. 719.

[17] Rozporzadzenie Ministra Rolnictwa i Gospodarki Żywnościowej z dnia 7 października 1997 r. w sprawie warunków technicznych, jakim powinny odpowiadać budowle rolnicze i ich usytuowanie, Dz.U. z 2014 r., poz. 81, tekst jednolity.

[18] Ustawa z dnia 21 grudnia 2000 r. o dozorze technicznym, Dz.U. z 2015 r. poz. 1125 z późn. zm., tekst jednolity.

[19] Ustawa z dnia 24 sierpnia 1991 r. o ochronie przeciwpożarowej, Dz.U. z 2016 r. poz. 191 z późn. zm., tekst jednolity.

[20] Gajewski A.: Elektryczność statyczna - poznanie, pomiar, zapobieganie, eliminowanie, Instytut Wydawniczy Związków Zawodowych, Warszawa 1987.

[21] Grabarczyk Z., Kurczewska, A.: Zagrożenia elektrostatyczne w strefach zagrożonych wybuchem, CIOP, Warszawa 2008.

[22] CLC/TR 50404:2003. Elektrostatyka - Kodeks postępowania praktycznego dla unikania zagrożeń zwiąanych z elektrycznościa statyczna.

[23] Kędzierski P.: Zmiana właściwości elektrostatycznych tkanin wykonanych $w$ technice przeplotu, "Wiadomości Górnicze" 2015, 4: 209-213.

[24] Kędzierski, P.: Antystatyzacja w ujęciu technologicznym "Wiadomości Górnicze" 2013, 12: 730-735.

[25] Dyrektywa ATEX 2014/34/EU Parlamentu Europejskiego i Rady $z$ dnia 26 lutego 2014 r. w sprawie harmonizacji ustawodawstwa państw członkowskich odnoszących się do urządzeń $i$ systemów ochronnych przeznaczonych do użytku w atmosferze potencjalnie wybuchowej.

[26] Dyrektywa 1999/92/WE Parlamentu Europejskiego i Rady $z$ dnia 16 grudnia 1999 r. w sprawie minimalnych wymagań dotyczacych bezpieczeństwa $i$ ochrony zdrowia pracowników zatrudnionych na stanowiskach pracy, na których może wystapić atmosfera wybuchowa.

PRZEMYSEAW KĘDZIERSKI, Ph.D., Eng. GIG Central Mining Institute pl. Gwarków 1, 40-166 Katowice, Poland pkedzierski@gig.pl 


\title{
Przegląd zagrożeń od elektryczności statycznej w górnictwie węgla kamiennego
}

\begin{abstract}
Zagrożenia wywołane elektrycznościq statyczna sa zaliczane do zagrożeń technicznych występujacych $w$ górnictwie węgla kamiennego. Zagrożenia te zwiazane sa z powstaniem nadmiarowego ładunku elektrycznego, będącego skutkiem większości czynności technologicznych. Największe zagrożenie stanowia wyroby z tworzyw sztucznych, kwalifikowanych jako materialy nieantyelektrostatyczne.

Omówiono regulacje europejskiego i polskiego prawa dotyczace wymagań dla materiatów $w$ zakresie ich właściwości antyelektrostatycznych. Przedstawiono wyniki badań prowadzonych w GIG pod katem usystematyzowania procesu antystatyzacji tworzyw sztucznych. Udowodniono, że proces nadania tworzywu sztucznemu wtaściwości antyelektrostatycznych nie jest latwy i jednorodny. Wprowadzona systematyka procesu antystatyzacji, czyli identyfikacja różnych metod realizacji procesu antystatyzacji, ma na celu uświadomienie producentom i odbiorcom istnienia wielu, często niepożądanych, wtaściwości modyfikowanych tworzyw sztucznych.
\end{abstract}

Słowa kluczowe: elektryczność statyczna, górnictwo, wybuch, tworzywo sztuczne

\section{WPROWADZENIE}

Wyroby wykorzystywane w górnictwie węgla kamiennego muszą spełniać wymagania antyelektrostatyczności, trudnopalności i nietoksyczności. Określa to rozporządzenie Ministra Gospodarki [1] - akt wykonawczy do ustawy Prawo geologiczne i górnicze [2]. Wyładowanie elektrostatyczne może stanowić źródło zapłonu metanu. Antyelektrostatyczność tych wyrobów nie jest rozumiana jednoznacznie i nie jest jednakowo realizowana.

Większość tworzyw sztucznych nie spełnia wymagań prawnych w zakresie właściwości antyelektrostatycznych. Wyroby z nich elektryzują się, gromadząc nadmiarowy ładunek elektryczny, co stanowi zagrożenie wyładowaniem elektrostatycznym, które może zainicjować zapłon atmosfery wybuchowej.

Tworzywa sztuczne, kwalifikowane jako izolatory elektryczne [3], są coraz częściej stosowane w górnictwie węgla kamiennego z uwagi na niższe koszty produkcji od kosztów materiałów antystatycznych. W celu spełnienia wymagań prawnych oraz obniżenia zdolności do elektryzacji tworzyw sztucznych przeprowadza się ich antystatyzację, czyli poprawianie właściwości antyelektrostatycznych. Antystatyzacja jest procesem polegającym na zmianie właściwości elektrostatycznych wyrobu w celu zwiększenia szybkości rozpraszania (odprowadzania) ładunków oraz zmniejszenia zdolności do elektryzacji.

Najczęściej antystatyzacja materiałów ma na celu zmianę ich rezystancji, która jest podstawowym parametrem oceny właściwości elektrostatycznych materiałów, i klasyfikacji - z materiału rozpraszającego na przewodzacy albo z izolatora na rozpraszający. $\mathrm{Na}$ podstawie rezystancji powierzchniowej i skrośnej materiały kwalifikuje się jako przewodzace, rozpraszające i izolatory. Dwa pierwsze rodzaje uznawane są za antystatyczne, czyli takie, które nie elektryzują się trwale i nie gromadzą ładunku na swojej powierzchni.

Istnieją różne metody realizacji procesu antystatyzacji. Wiele materiałów antystatyzowanych zmienia swoje właściwości elektrostatyczne w czasie lub ulegają one zmianie wskutek działania czynników zewnętrznych. Część z nich oddziałuje również na otoczenie. Materiały te, antystatyzowane różnymi metodami, mają wiele właściwości, nie zawsze pożądanych ze względów bezpieczeństwa i cech użytkowych. Niewłaściwy, nietrwały wyrób może mieć wpływ na bezpieczeństwo w strefach zagrożonych wybuchem. 


\section{ZAGROŻENIA W KOPALNIACH WĘGLA KAMIENNEGO}

Poniżej przedstawiono podział zagrożeń oparty na analizie literatury, głównie aktów prawa europejskiego, polskiego i norm.

Zagrożenia związane z elektrycznością statyczną rozważać można w następujących obszarach:

- komfort i bezpieczeństwo człowieka,

- przemysł elektroniczny i wytwarzający elementy wrażliwe na wyładowania typu ESDS,

- przemysł,

- atmosfery wybuchowe, w tym górnictwo węgla kamiennego,

- sale operacyjne.

Pierwszy obszar zagrożeń to komfort człowieka i jego bezpieczeństwo. Obszar komfortu nie jest uregulowany ani aktami prawnymi, ani normami - nie wyznaczono żadnych kryteriów oraz metod badań parametrów elektrostatycznych. Stosowanie obuwia bądź odzieży klasyfikowanych jako izolator lub materiał rozpraszający zależy tylko od danej osoby. W tym obszarze często człowiek jest naelektryzowany, dochodzi do wyładowań elektrostatycznych i w konsekwencji do wypadków, nawet śmiertelnych. Dla przykładu można podać uszkodzenie kończyn wskutek upadku będącego efektem odruchu bezwarunkowego po wyładowaniu z ciała człowieka do metalowej poręczy (człowiek w izolujących butach w czasie chodzenia uległ naelektryzowaniu).

Bezpieczeństwo człowieka w pracy, w zakresie ochrony przed elektrycznością statyczną reguluje w prawie europejskim dyrektywa [4] dotycząca środków ochrony osobistej, a w prawie polskim - rozporządzenie Ministra Gospodarki [5], rozporządzenie Ministra Infrastruktury [6], rozporządzenie Ministra Infrastruktury [7] oraz rozporządzenie Ministra Pracy i Polityki Społecznej [8]. Wymienione rozporządzenia stanowią akty wykonawcze do ustaw Kodeks pracy [9] i Prawo budowlane [10]. Wskazane w nich wymagania dotyczą ochrony przed elektrycznością statyczną, w tym głównie przed nadmierną elektryzacją.

Drugi obszar zagrożeń obejmuje ochronę przyrządów elektronicznych i wrażliwych na wyładowania elektrostatyczne tak zwanych obiektów typu ESDS. Jest to obszar bogaty w normy (rodzina norm serii PN-EN 61340 i IEC 61340). Niestety, obszaru tego nie regulują akty wykonawcze, tzn. stosowanie norm nie jest przymusem, a wyłącznie dobrą wolą producenta, chęcią zainwestowania w ochronę antystatyczną. Coraz częściej jednak producenci lub odbiorcy żądają od swoich dostawców wdrożenia rozwiązań z norm serii
PN-EN 61340 i IEC 61340, ponieważ mogą w ten sposób zagwarantować jakość i trwałość wyrobu, wykluczając na przykład wyładowanie elektrostatyczne z odzieży pracownika do układu elektronicznego. Uszkodzenie układu elektronicznego stanowi ukrytą wadę, która ujawnia się w czasie eksploatacji, a jest nie do wykrycia na etapie produkcji.

W przemyśle elektronicznym i związanym z komponentami wrażliwymi na ESD ma zastosowanie szereg norm określających metody kontroli, badań oraz działań prewencyjnych, mających na celu zapewnienie bezpiecznego manipulowania (najczęściej podczas produkcji) elementami elektronicznymi. Komponenty elektroniczne (płyty drukowane, mikroprocesory) mogą ulec zniszczeniu wskutek wyładowania ładunku o potencjale $50 \mathrm{~V}$. Stosowanie norm opisujących metody badań i kontroli w przemyśle elektronicznym nie jest przymusowe ani wymagane przez prawo. Coraz częściej wdrożenie wymagań tych norm wynika z potrzeby zapewnienia jakości produkcji i produktów w przedsiębiorstwach elektronicznych.

Trzeci obszar zagrożeń obejmuje przemysł, głównie związany z materiałami niebezpiecznymi i palnymi [11]. Bezpieczeństwo człowieka w pracy w zakresie ochrony przed elektrycznością statyczną reguluje w prawie europejskim dyrektywa [12] dotycząca maszyn, a w prawie polskim rozporządzenie Ministra Gospodarki [13].

W polskich przepisach można znaleźć: rozporządzenie Ministra Gospodarki [14], rozporządzenie Ministra Transportu [15], rozporządzenie Ministra Spraw Wewnętrznych i Administracji [16] oraz rozporządzenie Ministra Rolnictwa i Gospodarki Żywnościowej [17], które stanowią akty wykonawcze do ustaw: o dozorze technicznym [18], Kodeks pracy [9], Prawo budowlane [10], o ochronie przeciwpożarowej [19]. Określone w nich wymagania dotyczą ochrony przed nadmierną elektryzacją tam, gdzie ładunek elektrostatyczny może stanowić zagrożenie.

Czwarty obszar zagrożeń dotyczy stref zagrożonych wybuchem. Jest on najbardziej restrykcyjny, a określone dla niego parametry antystatyczne wynikają z dyrektyw Unii Europejskiej, rozporządzeń właściwych ministrów oraz norm jako aktów wykonawczych. Kontrola właściwości elektrostatycznych materiałów, ich ocena oraz posiadanie certyfikatu są niezbędne w przypadku stosowania ich w strefach zagrożonych wybuchem.

Dyrektywa maszynowa 2006/42/WE [12] wymaga od producentów maszyn, żeby projekty oraz wykonania maszyn i urządzeń zapewniały zapobieganie i ograniczanie gromadzenia się niebezpiecznych ładunków elektrostatycznych lub posiadały systemy do odprowadzania ładunków. 
Dyrektywa ATEX 2014/34/EU [25] ma na celu ujednolicenie przepisów państw członkowskich Unii Europejskiej dotyczących urządzeń elektrycznych i nieelektrycznych oraz systemów ochronnych przeznaczonych do użytku w przestrzeniach zagrożonych wybuchem. Uregulowania zawarte $\mathrm{w}$ tym przepisie dotyczą bezpieczeństwa i ochrony życia. Dyrektywa nakazuje zapobieganie wybuchom $\mathrm{w}$ wyniku stosowania odpowiednich środków zapobiegających powstawaniu ładunków elektrostatycznych zdolnych do wywołania niebezpiecznych wyładowań.

Zadaniem dyrektywy ATEX USERS 1999/92/WE [26] jest określenie minimalnych wymagań dotyczących bezpieczeństwa i ochrony zdrowia pracowników zatrudnionych w miejscach, gdzie może wystąpić atmosfera wybuchowa oraz narzucenie na pracodawce określonych obowiązków w tym zakresie. Obowiązkiem pracodawcy jest między innymi ocena ryzyka, podejmowanie technicznych działań mających eliminować i minimalizować zagrożenie. Zapobieganie zapłonowi ma uwzględniać możliwość wyładowania elektrostatycznego w miejscach, gdzie pracownicy lub środowisko pracy może być źródłem lub nośnikiem napięcia.

Dyrektywa dotycząca środków ochrony indywidualnej 89/686/EWG [4] ma na celu ujednolicenie w państwach członkowskich wymagań w zakresie wyposażenia ochrony osobistej oraz metod oceny zgodności. Dyrektywa nakazuje, aby środki ochrony osobistej przewidziane do użytku w atmosferach potencjalnie wybuchowych nie mogły być źródłem iskry ani łuku elektrycznego spowodowanego elektryzacją. Dyrektywa specyfikuje środki ochronne w strefach zagrożonych wybuchem, jako wyroby antystatyczne w całym okresie ich stosowania (to znaczy o niezmiennych parametrach). Środki ochronne muszą być wykonane z materiałów, które nie stanowią zagrożenia w aspekcie elektryczności statycznej.

Raport techniczny CLC/TR 50404 [22] został opracowany na podstawie mandatu udzielonego przez Komisję Europejską. Raport zawiera szereg istotnych informacji praktycznych związanych z wdrożeniem środków ochrony antystatycznej. W raporcie zawarto szczegółowe informacje na temat bezpiecznego stosowania większości powszechnie używanych materiałów i wyrobów w górnictwie oraz strefach zagrożonych wybuchem. Raport techniczny posiada wiele powiązań z publikacjami naukowymi i wynikami prac doświadczalnych.

Ustawa z dnia 09.06.2011 r. Prawo geologiczne i górnicze [2] wskazuje właściwego ministra do spraw gospodarki jako odpowiedzialnego za określenie szczegółowych wymagań dotyczących prowadzenia ruchu poszczególnych rodzajów zakładów górniczych w zakresie bezpieczeństwa i higieny pracy.

\section{ELEKTRYCZNOŚĆ STATYCZNA}

W elektrostatyce wprowadzono podziały materiałów ze względu na ich cechy elektrostatyczne. Podziały te zależą od dziedziny zastosowań, różne są w elektronice, bezpieczeństwie wybuchowym i innych obszarach.

Na podstawie kryterium rezystancji powierzchniowej powstał podział (rys. 1) na materiały: elektrostatycznie przewodzące (w tym materiały ekranujące), elektrostatycznie rozpraszające oraz izolatory [20].

Do powstania ładunków elektrostatycznych dochodzi podczas elektryzacji. Elektryzacja, czyli rozdzielenie ładunków elektrycznych ujemnych od dodatnich, polega na wyodrębnieniu ich $\mathrm{z}$ materii lub oddaleniu ich od siebie [21]. Do elektryzacji dochodzi podczas czynności, takich jak: tarcie, rozdzielanie, rozbryzgiwanie, przelewanie, rozdrabnianie, przemiany termiczne, procesy mechaniczne, zmiany stanów skupienia, indukcja elektryczna. Wszystkie te zjawiska można łatwo zidentyfikować nie tylko w życiu codziennym, ale również w wielu procesach produkcyjnych i technologicznych.

W ocenie zdolności do elektryzacji przeanalizować należy szereg tryboelektryczny, czyli uporządkowanie materiałów pod względem biegunowości i wielkości ładunku elektrycznego wytwarzanego podczas metod kontaktowo-tarciowych. Niektóre materiały łatwiej tracą elektrony, inne łatwiej je gromadzą (rys. 2).

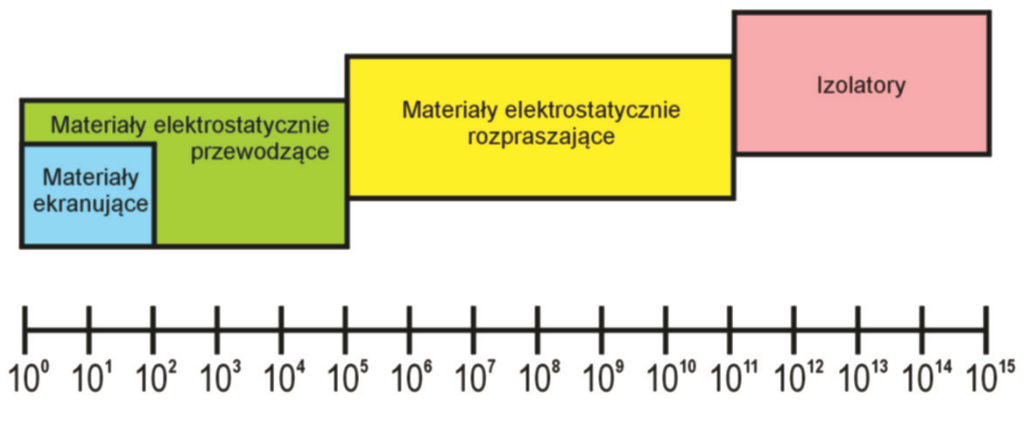

Rezystancja powierzchniowa, $\Omega$

Rys. 1. Podział materiałów ze względu na ich cechy elektrostatyczne 


\section{Ładunki dodatnie

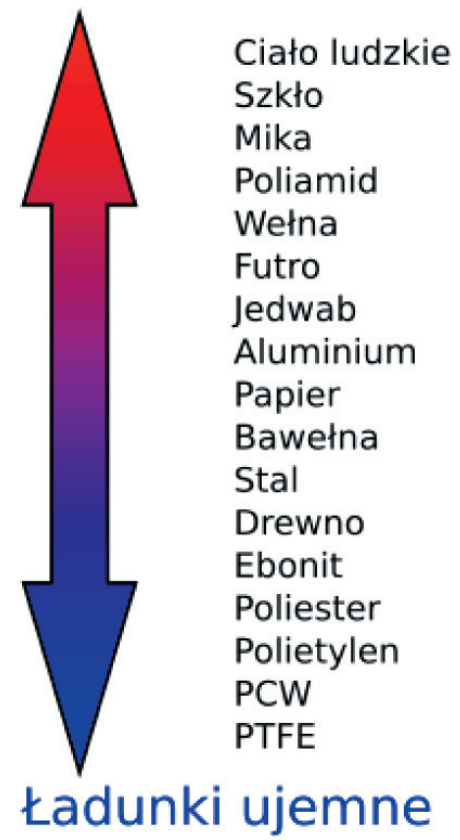

Rys. 2. Szereg tryboelektryczny

Najpowszechniejszym sposobem elektryzacji jest elektryzacja przez tarcie i kontakt, nazywana również metodą kontaktowo-tarciową lub stykową. Na granicy styku dwóch ciał dochodzi do wymiany elektronów - tak zwana warstwa podwójna. W następstwie rozdzielenia tych ciał, na jednym z nich wystąpi nadmiar elektronów (ładunki ujemne), natomiast na drugim ciele wystąpi niedomiar elektronów (ładunki dodatnie). Liczba powstałych nadmiarowych ładunków uzależniona jest od właściwości powierzchni, rodzaju materiału, docisku oraz parametrów otoczenia.

W czasie rozdzielania - zgodnie z zasadą szeregu tryboelektrycznego - w zależności od charakteru powinowactwa elektronowego, materiały oddają lub przyjmują elektrony, doprowadzając do powstania nierównowagi elektrycznej w materiałach $-\mathrm{w}$ jednym przewagi elektronów, a w drugim ich niedomiaru. Przykładem może być odrywanie stóp od podłoża (rys. 3) lub otwieranie książki w foliowej okładce.

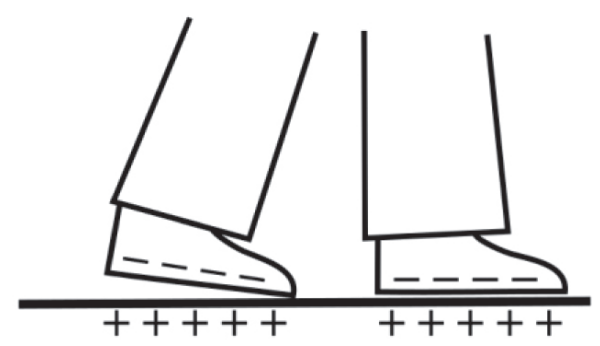

Rys. 3. Przyktad elektryzacji przez kontakt odrywanie stóp od podtoża
Elektryzacja przez tarcie, podobnie jak przez kontakt, związana jest $\mathrm{z}$ szeregiem tryboelektrycznym. Wskutek tarcia mechanicznego dochodzi do przechodzenia ładunków elektrycznych między ciałami w wyniku tego ciała elektryzują się nadmiarowym ładunkiem elektrycznym. $\mathrm{Z}$ badań znaku ładunku podczas elektryzacji metodami kontaktowo-tarciowymi można wyciągnąć wniosek, że znak ładunku zależy w wielu przypadkach od sposobu elektryzacji. Nie przeprowadzono badań nad wpływem na elektryzację tarciową elektryzacji kontaktowej i odwrotnie (w tym rozdzielanie i uderzanie). Częścią elektryzacji przez tarcie jest elektryzacja przy przerywaniu kontaktu.

\section{ANTYSTATYZACJA}

Antystatyzacja, czyli nadanie materiałowi cech antystatycznych, jest procesem polegającym na zmianie właściwości elektrycznych wyrobu, realizowanym w celu zwiększenia szybkości rozpraszania (odprowadzania) ładunków lub zmniejszenia zdolności do elektryzacji albo zwiększenia szybkości rozpraszania (odprowadzania) ładunków i zmniejszenia zdolności do elektryzacji.

Niektóre antystatyki (napełniacze), dodawane w celu nadania pewnych cech, np. koloru, posiadaja właściwości antystatyczne i wpływają na zmianę właściwości elektrycznych modyfikowanego materiału, jednak nie są one traktowane jako antystatyki, a ich użycie nie jest traktowane jako proces antystatyzacji.

Ze względu na właściwości elektrostatyczne [22] materiały dzielimy na: ekranujące, przewodzące, rozpraszające i izolatory. Kryterium ich podziału jest rezystancja powierzchniowa. $\mathrm{Z}$ uwagi na to antystatyzację można uznać za proces polegający na zmianie rezystancji materiału: $z$ rozpraszającego na przewodzący, $\mathrm{z}$ izolatora na rozpraszający lub $\mathrm{z}$ izolatora na przewodzący. Proces antystatyzacji przedstawiono na rysunku 4.

Na szybkość odprowadzenia ładunku z materiału ma wpływ również pojemność elektryczna (1), jednak antystatyzacja nie jest utożsamiana ze zmianą pojemności elektrycznej wyrobu chociażby dlatego, że trudno jest modyfikować i sterować pojemnością elektryczną tworzywa sztucznego. Ponadto nie ma opracowanej znormalizowanej metody do pomiaru pojemności elektrycznej wyrobów. Dodanie do wyrobu chociażby metalowych elementów, poza modyfikacją pojemności elektrycznej, zmienia też jego rezystancję. 


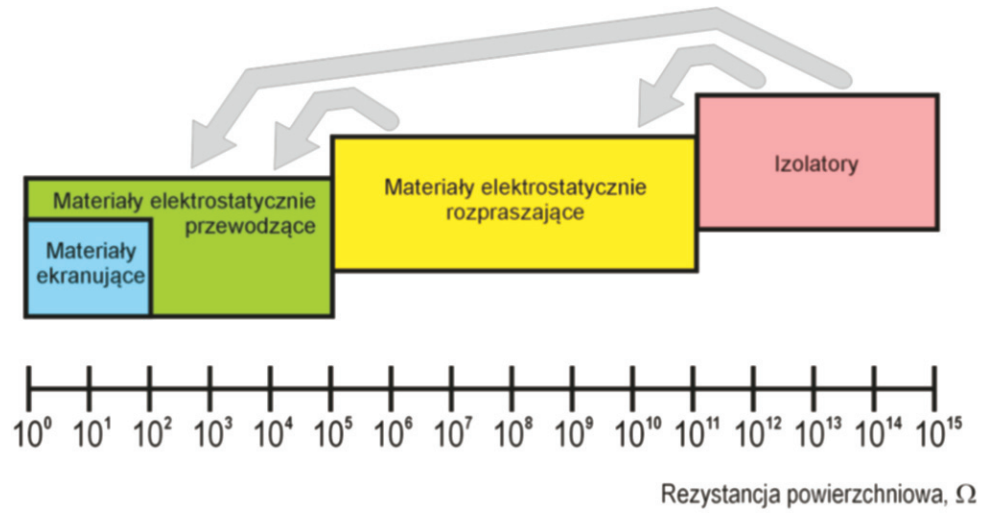

Rys. 4. Podziat materiałów ze względu na ich rezystancję oraz proces antystatyzacji

Zanik ładunku (rozładowanie lub odprowadzenie nadmiarowego ładunku elektrostatycznego z obiektu do uziemienia lub ziemi) opisane jest funkcją wykładniczą:

$$
Q(t)=Q_{0} e^{-\frac{t}{R C}}
$$

Z zależności (1) wynika, że na szybkość rozładowania decydujący wpływ ma pojemność elektryczna i rezystancja wyrobu. W badaniach pojemność elektryczną wyrobu potraktowano jako cechę wyrobu określającą jego zdolność do kumulacji ładunków. Jeśli przyjmie się, że antystatyzowany materiał jest odizolowany, to całkowity ładunek elektrostatyczny naniesiony na materiał pozostanie na nim. Od rezystancji materiału zależy, czy ładunek elektrostatyczny rozproszy się po całej powierzchni lub objętości materiału, czy też pozostanie w miejscu powstania (naniesienia). Rozkład powierzchniowy ładunku na odizolowanym materiale ma duże znaczenie, ponieważ decyduje o wielkości ładunku elektrycznego na jego powierzchni. Od pojemności elektrycznej wyrobu, niezależnie od wielkości zgromadzonego na nim ładunku elektrostatycznego, zależy potencjał elektrycz- ny obiektu naelektryzowanego, a w konsekwencji energia wyładowania elektrostatycznego.

\section{METODY REALIZACJI PROCESU ANTYSTATYZACJI}

Na podstawie własnych badań, spostrzeżeń i wniosków dokonano podziału procesu antystatyzacji (rys. 5) ze względu na trzy cechy: rodzaj procesu antystatyzacji, rodzaj preparacji (użytego napełniacza) oraz miejsce przeprowadzania procesu antystatyzacji w całym procesie produkcji [23]. Stosując podział procesu antystatyzacji, jak na rysunku 5, zidentyfikowano osiem metod realizacji procesu antystatyzacji tworzyw sztucznych, co determinuje osiem różnych rodzajów materiałów antystatyzowanych (rys. 6).

Każdy wyrób antystatyzowany można rozpatrywać według podziału zobrazowanego na rysunku 5 , charakteryzując go ze względu na: rodzaj antystatyzacji, rodzaj preparacji i miejsce przeprowadzania - kwalifikując jako jeden z ośmiu rodzajów materiałów antystatyzowanych.

Wyodrębnienie ośmiu metod realizacji procesu antystatyzacji materiałów ma znaczenie w ocenie realizacji procesu antystatyzacji [24].

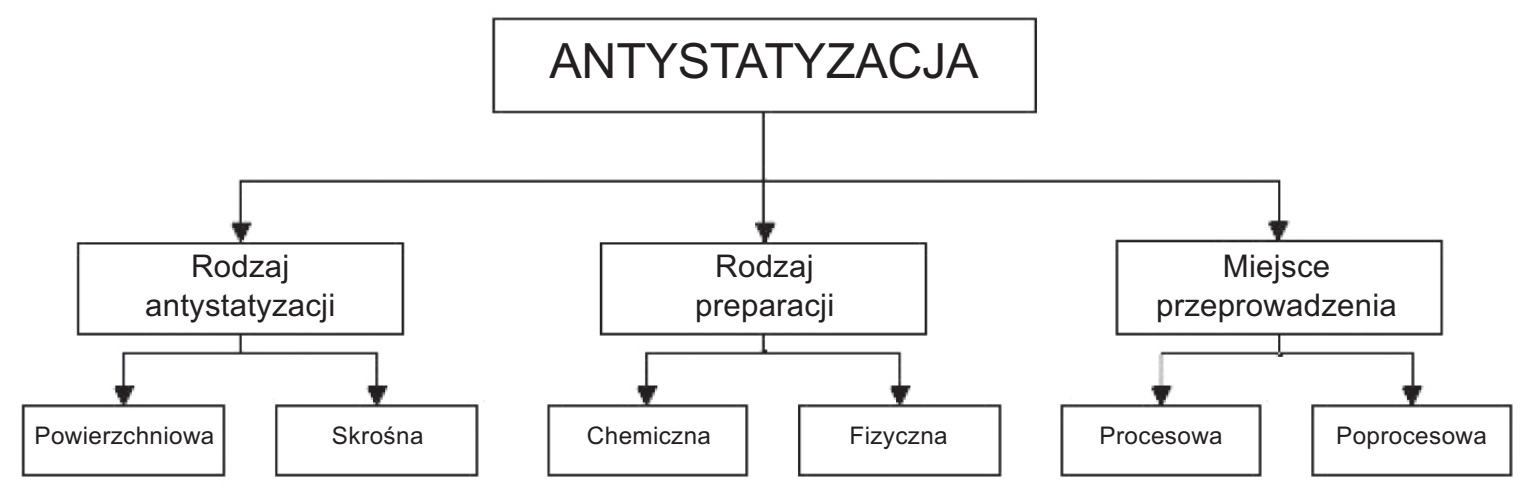

Rys. 5. Podziat procesu antystatyzacji 


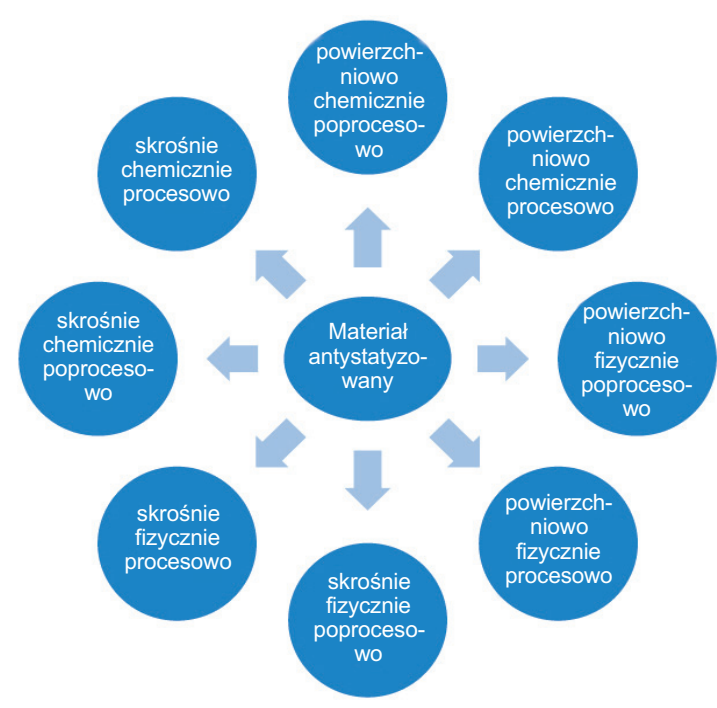

Rys. 6. Rodzaje materiałów antystatyzowanych

\section{PODSUMOWANIE}

W publikacji podjęto się identyfikacji, charakterystyki i oceny różnych metod realizacji procesu antystatyzacji tworzyw sztucznych używanych powszechnie w górnictwie węgla kamiennego. Wydawać by się mogło, że proces antystatyzacji jest prostym sposobem obniżenia zdolności do elektryzacji materiałów. Dokonana identyfikacja jest propozycją własną autora, opracowaną na podstawie wieloletnich badań własnych i spostrzeżeń oraz oceny korelacji (współzależności i wzajemnych powiązań) parametrów elektrycznych. $\mathrm{Na}$ podstawie badań i spostrzeżeń opracowano różne metody realizacji procesu antystatyzacji, które charakteryzują się właściwościami związanymi bezpośrednio $\mathrm{z}$ bezpieczeństwem wybuchowym w kopalniach. Przedstawione metody antystatyzacji ocenione zostały pod kątem ich bezpiecznego użycia.

Dobrano właściwą metodologię badań właściwości antystatycznych materiałów. Przyjęty katalog badań pozwolił jednoznacznie zidentyfikować metody realizacji procesu antystatyzacji. Niektóre metody badań, jak np. zdolność do elektryzacji, zdyskwalifikowano jako właściwy sposób pomiaru do identyfikacji metody antystatyzacji. Metody badań dobrano tak, żeby wyniki pomiarów niosły z sobą informacje na temat metody antystatyzacji. Zaproponowany podział metod badań na parametry statyczne i dynamiczne pozwolił na sformułowanie wniosków dotyczących współzależności tych parametrów. Wzajemne powiązania odpowiednich parametrów elektrostatycznych opisują wyrób według podziału przyjętego przez autora, uwzględniającego: typ antystatyzacji, rodzaj preparacji i miejsce przeprowadzania antystatyzacji.
W publikacji opisano dwa procesy antystatyzacji. W pierwszym modyfikowano tworzywo sztuczne folię techniczną. W drugim modyfikowano folię górniczą dzięki wykorzystaniu trzech różnych antystatyków i dodatkowo każdy z nich w dwóch różnych stężeniach. Procesy antystatyzacji przeprowadzono według zidentyfikowanych w pracy metod.

W ramach pracy podjęto się oceny skuteczności różnych sposobów realizacji procesu antystatyzacji. Jako skuteczność należy rozumieć ocenę wyrobu finalnego oraz spełnienie zaplanowanych wymagań co do cech antystatycznych wyrobu. Udowodniono, że część zidentyfikowanych metod antystatyzacji charakteryzuje się dużą niejednorodnością wyrobu finalnego, nietrwałością jego antystatyzacji w czasie lub wpływem na otoczenie przez procesy wyparowywania czy łuszczenia materiału antystatyzowanego. Zaobserwowano, że trwałość cech materiałów antystatyzowanych niektórymi metodami jest zależna od czynników panujących w kopalniach, takich jak wilgotność względna, atmosfera kopalniana - tracą one swoje cechy antystatyczne, np. po przepłukaniu wodą.

\section{WNIOSKI}

Stosowane w górnictwie węgla kamiennego wyroby muszą spełniać wymagania polskiego prawa $\mathrm{w}$ zakresie parametrów technicznych zapewniających ich bezpieczną eksploatację. Rozporządzenie Ministra Gospodarki z dnia 28 czerwca 2002 r. w sprawie bezpieczeństwa i higieny pracy, prowadzenia ruchu oraz specjalistycznego zabezpieczenia przeciwpożarowego w podziemnych zakładach górniczych (Dz.U. z 2002 r. nr 139, poz. 1169), jako akt wykonawczy do ustawy Prawo geologiczne i górnicze (Dz.U. z 2016 r., poz. 1131), dopuszcza do stosowania w podziemnych wyrobiskach wyroby z tworzyw sztucznych, które charakteryzują się trudnopalnością, antystatycznością i nietoksycznością. $\mathrm{Z}$ analizy literatury wynika, że zdecydowana większość tworzyw sztucznych nie ma właściwości antystatycznych. Stwierdzić można, że wszystkie wyroby z tworzyw sztucznych stosowane w górnictwie są antystatyzowane, ponieważ prawo wymaga posiadania przez nie parametrów antystatycznych. Od sposobu i rodzaju antystatyzacji zależy jakość finalnego wyrobu użytkowanego w kopalni. Wyrób antystatyzowany powinien być trwały i nie powinien pogarszać komfortu pracy górników, ponieważ od sposobu realizacji procesu antystatyzacji zależy bezpieczeństwo ludzi pracujących w strefach zagrożonych wybuchem w polskim górnictwie węgla kamiennego. 
W trakcie realizacji pracy dostrzeżono brak spełniania przez wyroby stosowane w podziemnych wyrobiskach pełnych wymagań bezpieczeństwa poprzez uzyskanie przez wyrób trwałych i bezpiecznych parametrów antystatycznych. Istnieją wyroby, które spełniają wymagania antystatyczności podczas badań, jednak po pewnym czasie te właściwości zanikają. Dostrzeżono również brak jednoznacznych wymagań prawnych w zakresie oceny właściwości elektrostatycznych wyrobów. Określenie dla wyrobu wymogu „posiadania cech antystatycznych” jest zdecydowanie zbyt ogólne. Należałoby je doprecyzować i uściślić. Stwierdzić można, chociażby na podstawie braku wzajemnych powiązań parametrów elektrycznych wyrobów antystatyzowanych, że obecny stan prawny dopuszcza jako bezpieczne wyroby spełniające kryterium rezystancji, a niespełniające kryterium czasu zaniku ładunku bądź odwrotnie.

Dynamiczny wzrost udziału tworzyw sztucznych w produkcji wyrobów używanych w przemyśle wpływa na zwiększenie ilości tworzyw sztucznych stosowanych w kopalniach. Wnioski sformułowane w rozprawie doktorskiej powinny być wykorzystane przez producentów tworzyw sztucznych używanych w polskim górnictwie węgla kamiennego. Producenci winni, nawet większymi nakładami finansowymi, produkować wyroby, które nie będą stanowić zagrożenia wybuchem przez cały okres użytkowania, ich parametry antystatyczne będą trwałe, a sposób realizacji procesu antystatyzacji nie będzie oddziaływał na środowisko albo pracowników podziemnych wyrobisk górniczych, pogarszając komfort pracy.

\section{Literatura}

[1] Rozporzadzenie Ministra Gospodarki z dnia 28 czerwca 2002 r. $w$ sprawie bezpieczeństwa $i$ higieny pracy, prowadzenia ruchu oraz specjalistycznego zabezpieczenia przeciwpożarowego w podziemnych zakładach górniczych, Dz.U. z 2002 r. nr 139, poz. 1169 z późn. zm.

[2] Ustawa z dnia 9.06.2011 r. - Prawo geologiczne i górnicze, Dz.U. z 2016 r., poz. 1131, tekst jednolity.

[3] Sukiennicki A., Zagórski A.: Fizyka ciała stałego, Wydawnictwa Naukowo-Techniczne, Warszawa 1984.

[4] Dyrektywa Rady 89/686/EWG z dnia 21 grudnia 1989 r. w sprawie ujednolicenia przepisów prawnych Państw Członkowskich odnoszacych się do wyposażenia ochrony osobistej.

[5] Rozporzadzenie Ministra Gospodarki z dnia 21 grudnia 2005 r. w sprawie zasadniczych wymagań dla środków ochrony indywidualnej, Dz.U. z 2005 r. nr 259, poz. 2173.

[6] Rozporzadzenie Ministra Infrastruktury $z$ dnia 12 kwietnia 2002 r. w sprawie warunków technicznych, jakim powinny odpowiadać budynki i ich usytuowanie, Dz.U. z 2015 r. poz. 1422; tekst jednolity.
[7] Rozporządzenie Ministra Infrastruktury z dnia 6 lutego $2003 \mathrm{r}$. w sprawie bezpieczeństwa i higieny pracy podczas wykonywania robót budowlanych, Dz.U. z 2003 r. nr 47, poz. 401.

[8] Rozporzadzenie Ministra Pracy i Polityki Spotecznej z dnia 11 czerwca $2002 \mathrm{r}$ w sprawie ogólnych przepisów bezpieczeństwa i higieny pracy, Dz.U. z 2003 r. nr 169, poz. 1650, tekst jednolity.

[9] Ustawa z dnia 26 czerwca 1974 r. - Kodeks pracy, Dz.U. z 2014 r. poz. 1502 z późn. zm., tekst jednolity.

[10] Ustawa z dnia 7 lipca 1994 r. - Prawo budowlane, Dz.U. z 2016 r. poz. 290 z późn. zm., tekst jednolity.

[11] Walp L.E.: Antistatic Agents. Kirk-Othmer Encyclopedia of Chemical Technology 2014.

[12] Dyrektywa 2006/42/WE Parlamentu Europejskiego i Rady $z$ dnia 17 maja 2006 r. w sprawie maszyn.

[13] Rozporzadzenie Ministra Gospodarki $z$ dnia 21.10.2008 r. w sprawie zasadniczych wymagań dla maszyn, Dz.U. z 2008 r. nr 199, poz. 1228 z późn. zm.

[14] Rozporządzenie Ministra Gospodarki z dnia 21 listopada 2005 r. $w$ sprawie warunków technicznych, jakim powinny odpowiadać bazy i stacja paliw płynnych, rurociagi przesytowe dalekosiężne stużace do transportu ropy naftowej i produktów naftowych i ich usytuowanie, Dz.U. z 2014 r. poz. 1853, tekst jednolity.

[15] Rozporzadzenie Ministra Transportu z dnia 20 listopada $2006 r$. w sprawie warunków technicznych dozoru technicznego, jakim powinny odpowiadać urządzenia do napetniania i opróżniania zbiorników transportowych, Dz.U. z 2015 r. poz. 34, tekst jednolity.

[16] Rozporządzenie Ministra Spraw Wewnętrznych i Administracji $z$ dnia 7 czerwca 2010 r. w sprawie ochrony przeciwpożarowej budynków, innych obiektów budowlanych i terenów, Dz.U. z 2010 r. nr 109, poz. 719.

[17] Rozporządzenie Ministra Rolnictwa i Gospodarki Żywnościowej z dnia 7 października 1997 r. w sprawie warunków technicznych, jakim powinny odpowiadać budowle rolnicze i ich usytuowanie, Dz.U. z 2014 r., poz. 81, tekst jednolity.

[18] Ustawa z dnia 21 grudnia 2000 r. o dozorze technicznym, Dz.U. z 2015 r. poz. 1125 z późn. zm., tekst jednolity.

[19] Ustawa z dnia 24 sierpnia 1991 r. o ochronie przeciwpożarowej, Dz.U. z 2016 r. poz. 191 z późn. zm., tekst jednolity.

[20] Gajewski A.: Elektryczność statyczna - poznanie, pomiar, zapobieganie, eliminowanie, Instytut Wydawniczy Związków Zawodowych, Warszawa 1987.

[21] Grabarczyk Z., Kurczewska A.: Zagrożenia elektrostatyczne w strefach zagrożonych wybuchem, CIOP, Warszawa 2008.

[22] CLC/TR 50404:2003. Elektrostatyka - Kodeks postępowania praktycznego dla unikania zagrożeń zwiąanych z elektrycznością statyczną.

[23] Kędzierski P.: Zmiana właściwości elektrostatycznych tkanin wykonanych $w$ technice przeplotu, „Wiadomości Górnicze” 2015, 4: 209-213.

[24] Kędzierski, P.: Antystatyzacja w ujęciu technologicznym, „Wiadomości Górnicze” 2013, 12: 730-735.

[25] Dyrektywa ATEX 2014/34/EU Parlamentu Europejskiego i Rady $z$ dnia 26 lutego 2014 r. $w$ sprawie harmonizacji ustawodawstwa państw członkowskich odnoszących się do urządzeń i systemów ochronnych przeznaczonych do użytku $w$ atmosferze potencjalnie wybuchowej.

[26] Dyrektywa 1999/92/WE Parlamentu Europejskiego i Rady z dnia 16 grudnia 1999 r. w sprawie minimalnych wymagań dotyczacych bezpieczeństwa i ochrony zdrowia pracowników zatrudnionych na stanowiskach pracy, na których może wystapić atmosfera wybuchowa.

dr inż. PRZEMYSŁAW KĘDZIERSKI Gtówny Instytut Górnictwa pl. Gwarków 1, 40-166 Katowice pkedzierski@gig.pl 